\title{
A multiplex endokrin neoplasia-2A szindrómáról egy család kapcsán
}

\author{
Hircsu Ildikó dr. ${ }^{1}$ - Gazdag Annamária dr. ${ }^{1}$ - Bodor Miklós dr. ${ }^{1}$ \\ Berta Eszter dr. ${ }^{1}$ - Andrási Mónika dr. ${ }^{2}$ - Kanyári Zsolt dr. ${ }^{2}$ \\ Győry Ferenc dr. ${ }^{2}$ - Barna Sándor dr. ${ }^{3}$ - Bhattoa Harjit Pal dr. ${ }^{4}$ \\ Nagy Béla dr. ${ }^{4}$ - Nagy V. Endre dr. ${ }^{1}$ - Erdei Annamária dr. ${ }^{1}$
}

${ }^{1}$ Debreceni Egyetem, Általános Orvostudományi Kar, Belgyógyászati Intézet, Endokrinológia Tanszék, Debrecen ${ }^{2}$ Debreceni Egyetem, Általános Orvostudományi Kar, Sebészeti Intézet, Debrecen

${ }^{3}$ Debreceni Egyetem, Általános Orvostudományi Kar, Nukleáris Medicina Tanszék, Debrecen

${ }^{4}$ Debreceni Egyetem, Általános Orvostudományi Kar, Laboratóriumi Medicina Intézet, Debrecen

\begin{abstract}
A szerzők egy multiplex endokrin neoplasia-2A (MEN2A) szindrómában szenvedő beteg esetét ismertetik, akinél 55 éves korban hasi panaszok miatti részletes kivizsgálás részeként derült fény kétoldali mellékvese-térfoglalásra és pajzsmirigygöbre. Az utóbbi miatt végzett thyreoidectomia szövettani lelete medullaris pajzsmirigy-carcinomát igazolt. A mellékvese-térfoglalások hormon- és képalkotó vizsgálatok alapján bilaterális phaeochromocytomának bizonyultak. Tünetmentes primer hyperparathyreosisra is fény derült. Laparoszkópos adrenalectomia és mellékpajzsmirigy-adenoma eltávolítása történt. A beteg pozitív családi anamnézise és a klinikai kép alapján felmerülő MEN2A-szindrómát genetikai vizsgálattal bizonyítottuk. Az elsőfokú rokonok szűrése során a beteg 25 éves lánygyermeke génhordozónak bizonyult, nála preventív thyreoidectomiára került sor, és a szövettan többgócú medullaris carcinomát igazolt. Az eset kapcsán a szerző́k áttekintik a MEN2A-szindróma klinikai jellemzőit, és hangsúlyozzák a genetikai vizsgálat és a családszứrés fontosságát.

Orv Hetil. 2020; 161(2): 75-79.
\end{abstract}

Kulcsszavak: medullaris pajzsmirigydaganat, phaeochromocytoma, primer hyperparathyreosis, 2A típusú multiplex endokrin neoplasia szindróma, genetikai vizsgálat

\begin{abstract}
Multiple endocrine neoplasia type $2 \mathrm{~A}$ in a family
The authors present the case of a multiplex endocrine neoplasia type 2A (MEN2A). The 55-year-old woman underwent detailed examinations for abdominal complaints. Bilateral adrenal masses and thyroid nodular goiter were found. Based on metanephrine excretion and MIBG imaging, bilateral phaeochromocytomas were diagnosed. The thyroid nodules were confirmed by thyroidectomy as bilateral medullary thyroid carcinoma. Asymptomatic primary hyperparathyroidism was also detected. Laparoscopic adrenalectomy and parathyroid adenoma removal were performed. Based on family history and the characteristic clinical presentation, MEN2A syndrome was confirmed by genetic testing. During genetic screening of first-degree relatives, the patient's 25-year-old daughter was shown to be a gene carrier. Preventive thyroidectomy was performed and histology proved multifocal medullary thyroid cancer. In addition to the importance of genetic testing, the authors emphasize the guideline-based, but individualized approach to patients with suspected MEN2A syndrome.
\end{abstract}

Keywords: medullary thyroid cancer, phaeochromocytoma, primary hyperparathyroidism, multiple endocrine neoplasia type $2 \mathrm{~A}$, genetic testing

Hircsu I, Gazdag A, Bodor M, Berta E, Andrási M, Kanyári Zs, Győry F, Barna S, Bhattoa HP, Nagy B, Nagy VE, Erdei A. [Multiple endocrine neoplasia type 2A in a family]. Orv Hetil. 2020; 161(2): 75-79.

(Beérkezett: 2019. július 22.; elfogadva: 2019. augusztus 31.) 


\section{Rövidítések}

$\mathrm{ABPM}=($ ambulatory blood pressure monitoring $) 24$ órás vérnyomás-monitorozás; CEA = carcinoembrionalis antigén; $\mathrm{CgA}$ $=($ chromogranin $\mathrm{A})$ kromogranin $-\mathrm{A} ; \mathrm{CT}=$ komputertomográ fia; $\mathrm{FMTC}=($ familial medullary thyroid carcinoma $)$ familiaris medullaris pajzsmirigy-carcinoma; MEN2A = multiplex endokrin neoplasia-2A; MIBI-mellékpajzsmirigyszcintigráfia = ${ }^{99 m}$ technécium-metoxi-izobutil-izonitril izotóp segítségével végzett képalkotó eljárás; MIBG-szcintigráfia = ${ }^{131}$ jód-metajodo-benzil-guanidin izotóp segítségével végzett képalkotó eljárás; PET-CT $=$ CT-vel kombinált pozitronemissziós tomográfia; $\mathrm{PTH}=$ parathormon; $\mathrm{tCa}=($ total calcium $)$ teljes kalcium; $\mathrm{UH}=$ ultrahang

A MEN2A-szindróma a multiplex endokrin neoplasiák egyik típusa. Eredetileg Sipple-szindróma néven 1961ben írták le először [1]. A multiplex endokrin neoplasiákra jellemző a családi halmozódású endokrin daganatok megjelenése, illetve egy egyénen belül akár többféle endokrin daganat előfordulása. A multiplex endokrin neoplasia szindrómáknak két típusuk van, a MEN1 - és a MEN2-szindróma. A MEN2-szindróma autoszomális domináns módon öröklődő megbetegedés, kialakulásáért a 10-es kromoszómán elhelyezkedő RET-protoonkogén mutációi felelősek $[2,3]$. Ezek két nagy csoportba oszthatók, aktiváló és inaktiváló mutációkra; a MEN2 kialakulásában az aktiváló mutációk játszanak fontos szerepet. Klinikai altípusai a MEN2A-, MEN2B-szindróma és a familiaris medullaris pajzsmirigy-carcinoma (FMTC). A MEN2A-ra jellemző a medullaris pajzsmirigy-carcinoma családon belüli gyakoribb előfordulása, önmagában vagy phaeochromocytomával és/vagy primer hyperparathyreosissal társulva [4]. A medullaris pajzsmirigy-carcinoma esetén használatos tumormarkerek a kalcitonin és a carcinoembrionalis antigén, melyek mütét előtti szintje jól korrelál a tumortömeggel, illetve a mútét után alkalmas a kezelés hatékonyságának lemérésére. A szérumkalcitonin-szint azonban nem korrelál a nyirokcsomó-metasztázisok előfordulásával [2]. A MEN2A-szindrómás betegeknél gyakorlatilag minden esetben (több mint 90\%-ban) megjelenik medullaris pajzsmirigy-carcinoma, melyhez 40-50\%-ban társul phaeochromocytoma, illetve az esetek körülbelül 20\%ában jelenik meg primer hyperparathyreosis [1]. A MEN2A-szindróma első manifesztációja általában a medullaris pajzsmirigy-carcinoma, mely a leggyakrabban 5 és 25 éves életkor között manifesztálódik [1]. Szoros genotípus-fenotípus korreláció figyelhető meg: az örökletes medullaris carcinoma általában fiatalabb életkorban jelenik meg, mint a sporadikus forma, C-sejt-hyperplasia előzi meg, és gyakran multifokális vagy bilaterális megjelenésû. A phaeochromocytoma katecholamintermeló tumor, melyre jellemző klasszikus triász a fejfájás, a fokozott verejtékezés és a palpitáció [5]. A familiaris phaeochromocytomás betegek gyakran tünetmentesek, ritkán fordulnak elő a klasszikus tünetek [7]. Primer hyperparathyreosis az igazolt MEN2A-szindrómás be- tegek körülbelül 20\%-ában fordul elő, a leggyakrabban a 634-es kodon mutációjának esetében figyelhető meg [1].

\section{Esetismertetés}

$\mathrm{Az} 55$ éves nőbeteg távolabbi kórelőzményében nagyobb betegség, mútét nem szerepelt. A jó általános állapotú beteg kivizsgálása 2016 tavaszán indult hasi panaszok miatt, melyek rövid időn belül spontán megszüntek. A hasi ultrahangvizsgálaton felmerült a kétoldali mellékvese-térfoglalás lehetősége, ezért hasi CT-vizsgálat történt, mely a bal oldalon $38 \times 26 \mathrm{~mm}$-es, a jobb oldalon $65 \times 42 \mathrm{~mm}$-es térfoglalást írt le. A nyaki UH göbös pajzsmirigyet írt le; a $13 \times 17 \mathrm{~mm}$-es pajzsmirigygöbból aspirációs citológiai mintavétel történt, mely Bethesda VI. volt, így a felmerülő rosszindulatú pajzsmirigydaganat gyanúja miatt 2016 májusában 'near total' (majdnem teljes) thyreoidectomia történt centralis lymphadenectomiával. A szövettani vizsgálat medullaris pajzsmirigyrákot igazolt. A szövettan a jobb lebenyben 14 mm-es, a bal lebenyben $12 \mathrm{~mm}$-es tumort mutatott, mely a medullaris pajzsmirigy-carcinoma orsósejtes variánsának felelt meg. Nekrózis, érbetörés nem volt, a pajzsmirigy egyéb területein autoimmun thyreoiditist írtak le.

A pajzsmirigymütét után került intézményünkbe a beteg további kivizsgálásra és kezelésre. Családi anamnézise a diagnosztika szempontjából nagyon informatív volt: édesanyját pajzsmirigygöb és phaeochromocytoma miatt operálták, fiútestvére metasztatikus neuroendokrin daganat (szövettani vizsgálat a mellékveséből történt) következtében hunyt el. A családi anamnézis ismeretében, illetve a betegnél diagnosztizált medullaris pajzsmirigycarcinoma és a képalkotó vizsgálatok által leírt kétoldali mellékvese-térfoglalás hátterében felmerült a MEN2Aszindróma lehetősége. Feltételeztük azt is, hogy a mellékvese-térfoglalások - bár a beteg normotenziós volt, és típusos paroxizmusokban jelentkező rosszullétei sem voltak - phaeochromocytomák lehetnek. Az örökletes phaeochromocytomák hátterében a MEN2A-szindrómán kívül felmerülhet még a MEN2B-szindróma, a familiaris paraganglioma szindrómák, a Von Hippel-Lindau-szindróma, illetve a neurofibromatosis l-es típusának lehetősége [1]. A 2016. júniusban készült laboratóriumi vizsgálat során az alábbi eltérések voltak: kalcitonin: $17,4 \mathrm{mg} / 1$ (referenciatartomány <11,8 $\mathrm{mg} / \mathrm{l}), \mathrm{CgA}: 370,5 \mathrm{mg} / \mathrm{l}(20,0-100,0 \mathrm{mg} / \mathrm{l})$, CEA: 8,3 $\mu \mathrm{g} / \mathrm{l}(<3,4 \mu \mathrm{g} / \mathrm{l})$. A vizeletmetanefrin-ürítés 10200 $\mathrm{nmol} / \mathrm{nap}(375-1506 \mathrm{nmol} / \mathrm{nap})$, a vizeletnormetanefrin-ürítés $5800 \mathrm{nmol} / \mathrm{nap}$ (573-1932 nmol/nap) volt, és a MIBG-szcintigráfia megerősítette a feltételezett diagnózist (1. ábra). ABPM-vizsgálat során egy-egy mérsékelten emelkedett vérnyomásérték fordult elő. MEN2A-szindrómás betegek többszervi manifesztációja esetén általában először a phaeochromocytoma mútéti eltávolítását szokták elvégezni, majd azt követi a többi szükséges mútét. Nagy dilemmát jelentett számunkra, 


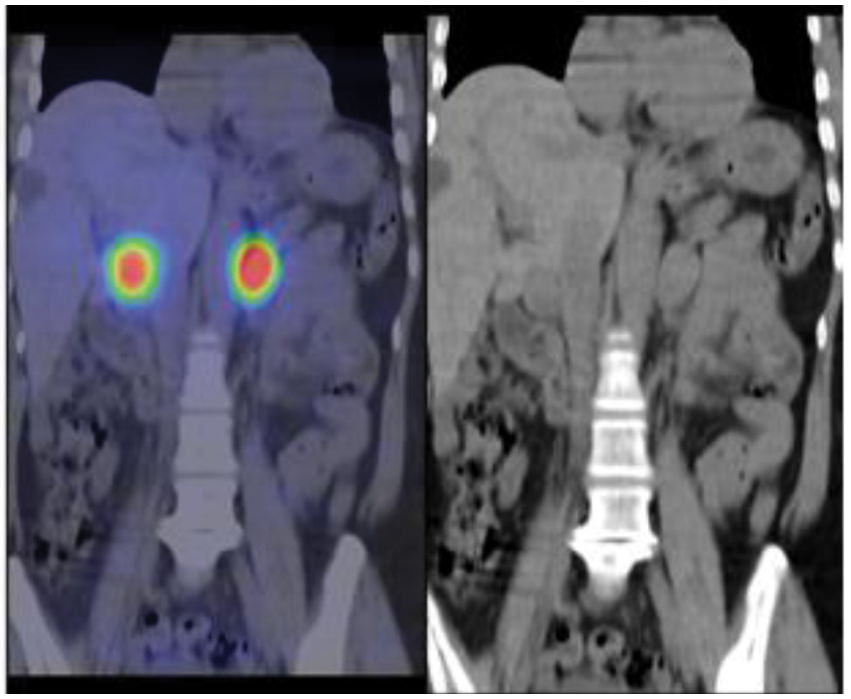

l. ábra | MIBG-szcintigráfia. Mindkét mellékvesében fokális dúsulás látszik, melyek phaeochromocytomának felelnek meg
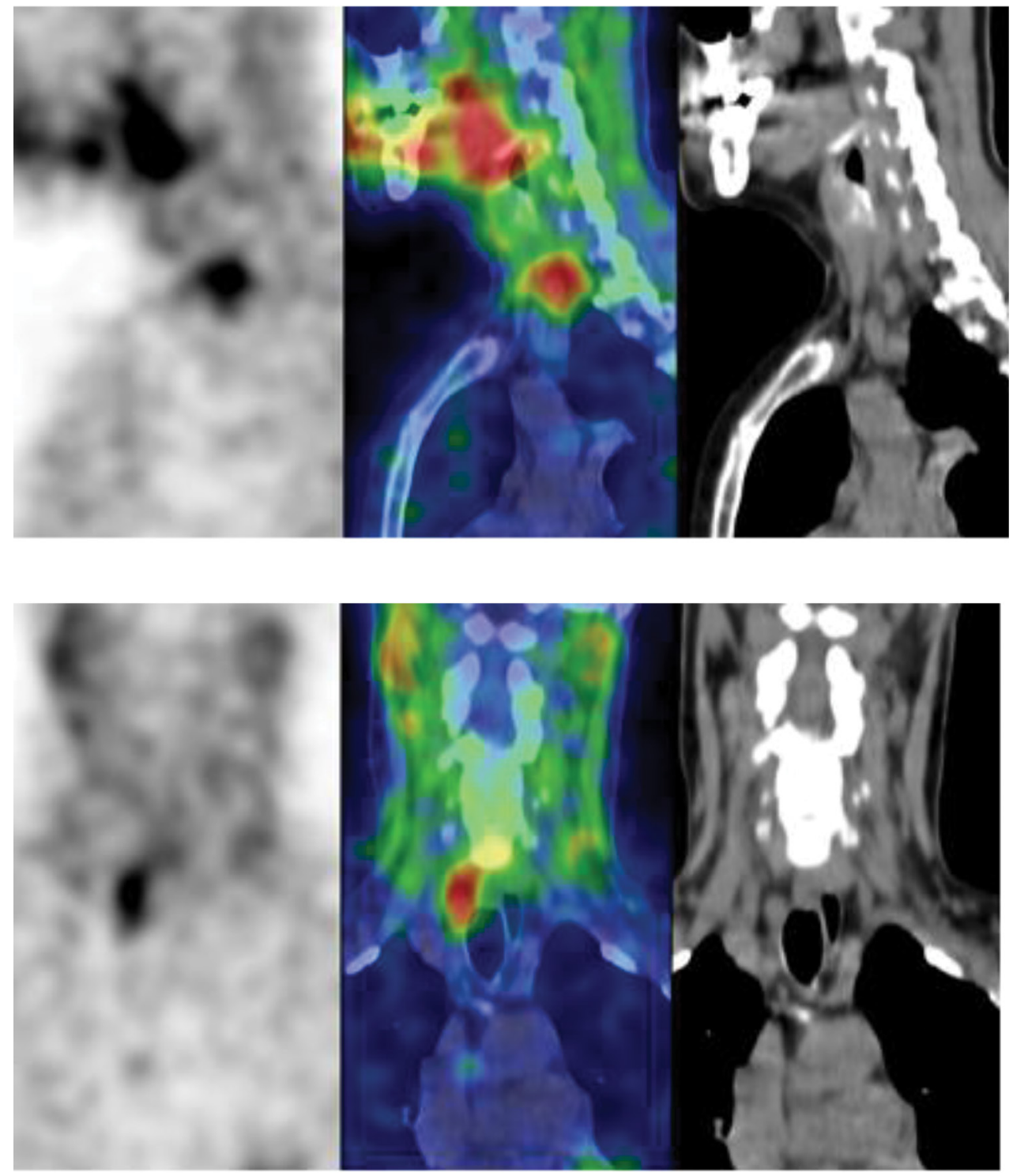

2. ábra $\quad$ MIBI-mellékpajzsmirigyszcintigráfia. Jobb oldalon paratrachealisan a thoracalis I. csigolya magasságában, egy $1,3 \mathrm{~cm}$ nagyságú, MIBI-t intenzíven halmozó, kerekded képlet ábrázolódik, mely mellékpajzsmirigy-adenomának megfelel 
hogy történjen-e bilaterális adrenalectomia. Végül mérlegelve, hogy irodalmi adatok szerint a MEN2A-szindrómában előforduló phaeochromocytomák gyakran kétoldaliak és szinte mindig benignusak, valamint azt a tényt, hogy a beteg panaszmentes volt, és jelzett hypertoniája kis dózisú monoterápiával jól kontrollálható volt, először a nagyobb méretü phaeochromocytoma eltávolítása és a kisebb méretü obszervációja mellett döntöttünk; 2016. októberben jobb oldali laparoszkópos adrenalectomia történt, melynek szövettani vizsgálata phaeochromocytomát igazolt. Ha kivitelezhető, örökletes, illetve bilaterális phaeochromocytoma esetén jó lehetőség a mellékvese-kímélő mútéti eljárás, mely a kétoldali adrenalectomia következtében kialakuló szövődményeket csökkentheti [7]. Esetünkben a mütét során ez nem volt kivitelezhető.

A kalcium- és parathormon (PTH)-meghatározás során már a vizsgálatok kezdetén igazolódott a MEN2Aszindrómára jellemző primer hyperparathyreosis. A kezdeti laborvizsgálatok során a tCa 2,63 mmol/1 (2,1-2,6 $\mathrm{mmol} / \mathrm{l})$, a PTH 12,36 pmol/1 (1,6-6,9 pmol/1) volt. A mellékpajzsmirigy-MIBI-scan ennek hátterében jobb oldali mellékpajzsmirigy-adenomát igazolt (2. ábra), melynek eltávolítására 2017. márciusban került sor. A mellékpajzsmirigy-mútét előtt a konzekvensen mérsékelten magasabb kalcitonin- és CEA-szint miatt nyaki és mellkasi CT, valamint PET-CT is történt negatív eredménnyel.

A genetikai vizsgálat során a RET-gén mutációja igazolódott, a 11 -es exon bidirekcionális szekvenálása alapján a Cys634-es kodonban egy TGC-CGC nukleotidcsere igazolódott heterozigóta formában (NM 020975.6(RET):c..1900T>C). A mutáció a 634-es po-

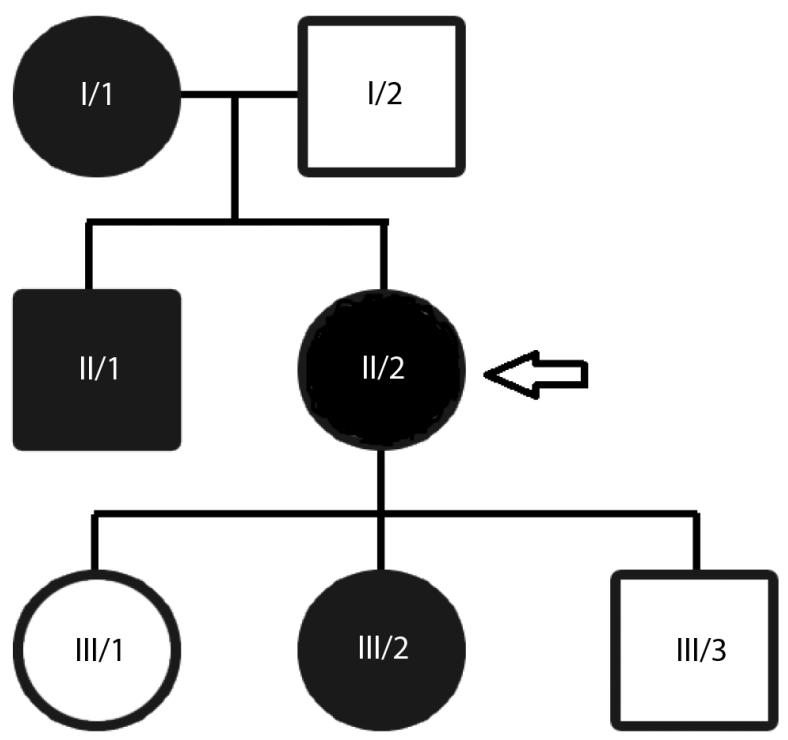

A MEN2A-szindrómás család családfája. Az ábrán nyíllal jelöltük az indexbeteget. A beteg édesanyja (I/l) és fiútestvére (II/1) anamnézisük alapján génhordozó volt, valamint genetikai szűrővizsgálat alapján egyik lánygyermeke (III/2) is az zícióban cisztein-arginin aminosavcserét eredményez (p.Cys634Arg), melynek következménye a RET ligand nélküli homodimerizációja és tirozinkináz-aktiválódás [8]. Miután igazolódott a genetikai eltérés, a beteg elsőfokú rokonainál (3 gyermekénél) genetikai szűrővizsgálatot végeztünk, melynek eredményeként egyik lánygyermekénél igazolódott a RET-gén mutációja (3. ábra).

A jobb oldali adrenalectomiát követően, mivel a beteg panaszmentes volt, és vérnyomása a normáltartományban volt, továbbra is a bal oldali mellékvese-térfoglalás obszervációja mellett döntöttünk. Követés során azonban az elváltozás növekedést mutatott: CT-vizsgálattal 2016. április és 2018. január között 38 mm-ről 50 mmre nőtt. Emiatt bal oldali laparoszkópos adrenalectomiára került sor.

A beteg jelenleg szubsztitúció mellett (tiroxin, hidrokortizon, fludrokortizon) panaszmentes, rendszeres ellenőrzésünk alatt áll.

A betegünk génmutációt hordozó 25 éves gyermekénél elvégzett, szürő jellegú laborvizsgálatok során kezdetben jelzetten emelkedett kalcitoninszintet észleltünk, amely az ismételt laborvizsgálat alkalmával a normáltartományban volt. A nyaki UH-on a jobb oldali pajzsmirigylebenyben $3 \mathrm{~mm}$-es, a bal oldaliban $4 \mathrm{~mm}$-es pajzsmirigyciszta ábrázolódott. Annak ellenére, hogy a nyaki UH-on leírt, $1 \mathrm{~cm}$ alatti ciszták „normál” esetben a követésen kívül teendőt nem igényelnek, a mutációhordozás miatt profilaktikus thyreoidectomia mellett döntöttünk. A szövettan mindkét oldalon $4 \mathrm{~mm}$-es medullaris pajzsmirigy-carcinomát igazolt. Egyéb, MEN2A-szindrómára jellegzetes laboreltérést nem észleltünk. CT-vizsgálattal a mellékvesék szabályos szerkezetûek voltak.

\section{Megbeszélés}

Jól ismert, hogy az igazolt MEN2A-szindrómás betegek elsőfokú rokonain el kell végezni a genetikai vizsgálatot a RET-gén-mutációra. A gyakori RET-mutációk genetikai vizsgálata a rutin laboratóriumi diagnosztikában Debrecenben 2002 óta érhető el. A profilaktikus thyreoidectomia tünet- és panaszmentes hordozókban nemritkán medullaris pajzsmirigy-carcinomát vagy C-sejthyperplasiát mutat. Javasolt a genetikai vizsgálat elvégzése a RET-protoonkogén mutációjára minden medullaris pajzsmirigy-carcinomás betegnél [3]. A medullaris pajzsmirigy-carcinoma egyetlen kuratív terápiája a sebészi eltávolítás [2]. A RET-gén-mutáció alapján háromféle rizikócsoport különíthető el a medullaris pajzsmirigy-carcinoma megjelenésének idejét illetően: mérsékelt, magas, legmagasabb rizikójú csoportok [2] (1. táblázat). A RET-gén-mutációt hordozó legmagasabb rizikójú csoportban a thyreoidectomia mihamarabbi elvégzése javasolt, lehetóleg az első életévben [2]. A magas rizikójú csoportba tartozó génmutációt hordozóknál a thyreoidectomia elvégzése 5 éves életkor alatt javasolt [2]. A mérsékelt rizikójú csoport esetében lehet várni a thyreoidectomia elvégzésével a szérumkalcitonin- 
1. táblázat $\mid$ A familiaris medullaris pajzsmirigy-carcinoma rizikócsoportjai a RET-mutációk alapján

\begin{tabular}{|c|c|}
\hline Rizikócsoportok & Mutációk \\
\hline Kevésbé agresszív & $\begin{array}{l}\text { A } 609 \text {-es, } 768 \text {-as, } 790 \text {-es, } 791 \text {-es, 804-es, } \\
891 \text {-es kodon mutációja }\end{array}$ \\
\hline Közepesen agresszív & $\begin{array}{l}\text { A } 611 \text {-es, 618-as, 620-as, 634-es kodon } \\
\text { mutációja }\end{array}$ \\
\hline Kifejezetten agresszív & $\begin{array}{l}\text { MEN2B-beteg vagy a } 883 \text {-as, } 918 \text {-as, } \\
\text { 922-es kodon mutációja }\end{array}$ \\
\hline
\end{tabular}

szint emelkedésének bekövetkeztéig, melyet 6-12 havonként ellenőrizni kell [2]. A cikkben bemutatott eset egyik különlegessége, hogy betegünknél viszonylag késői életkorban igazolódott a MEN2A-szindróma. A medullaris pajzsmirigy-carcinoma a MEN2A-szindrómának általában az első manifesztációja, melyet a leggyakrabban 5 és 25 éves kor között diagnosztizálnak [8]. Ezen szindrómában a leggyakrabban előforduló daganat a medullaris pajzsmirigy-carcinoma, mely a génmutációt hordozó betegekben a 40 éves életkor eléréséig szinte mindig kialakul. Egy, az Egyesült Államokban elvégzett tanulmány alapján a MEN2A-szindrómában a medullaris pajzsmirigydaganat diagnosztizálásakor az átlagéletkor 26 év, a phaeochromocytomák diagnosztizálásakor pedig 34 év [9]. A bemutatott eset jól illusztrálja, hogy a nemzetközi protokollok iránymutatása mellett az adott beteg kezelésében egyéni szempontokat kell figyelembe venni.

Anyagi támogatás: A szerzők anyagi támogatásban nem részesültek.

Szerzői munkamegosztás: H. I.: A kézirat elkészítése, az esetismertetésben szereplő betegek kezelése, a klinikai adatok összegyújtése. G. A., B. M., B. E., A. M., K. Zs., Gy. F.: Az esetismertetésben szereplő betegek kezelése, a klinikai adatok összegyüjtése. B. S.: Az esetismertetés- ben szereplő beteg izotópvizsgálatainak elvégzése, a klinikai adatok összegyújtése. B. H. P.: A laboratóriumi vizsgálatok elvégzése. N. B.: A genetikai vizsgálat elvégzése. N. V. E.: A kézirat ellenőrzése. E. A.: A kézirat elkészítése, az esetismertetésben szereplő betegek kezelése. A cikk végleges változatát valamennyi szerző elolvasta és jóváhagyta.

Érdekeltségek: A szerzőknek nincsenek érdekeltségeik.

\section{Irodalom}

[1] Goran A, Peter S. Surgical management of MEN-1 and -2: state of the art. Surg Clin N Am. 2009; 89: 1047-1068.

[2] Friedhelm R, Karin F-R. Update on multiple endocrine neoplasia type 2: focus on medullary thyroid carcinoma. J Endocr Soc. 2018; 2: 933-943.

[3] Nelson W, Heiko S, Zoran E, et al. Multiple endocrine neoplasia type 2. Clin Endocrinol Metab. 2010; 24: 371-387.

[4] Al-Salameh A, Baudry C, Cohen R. Update on multiple endocrine neoplasia type 1 and 2. Presse Med. 2018; 47: 722-731.

[5] Lavalle-Martinez J, Suarez-Montalvo M. Pheochromocytoma in multiple endocrine neoplasia $2 \mathrm{~A}$ associated with pulmonary tuberculosis presenting as abdominal pain: a case report and literature review. Medwawe 2018; 18: 7320.

[6] Shipra A, Vandana T, Pooja V, et al. Anesthetic managment of clinically silent familial pheochromocytoma with MEN 2A: a report of four cases. Indian J Surg. 2016; 78: 414-417.

[7] Frederic C, Xiao-Ping Q, Martin KW, et al. Outcomes of adrenal-sparing surgery or total adrenalectomy in phaeochromocytoma associated with multiple endocrine neoplasia type 2 : an international retrospective population-based study. Lancet Oncol. 2014; 15: 648-655.

[8] Romei C, Pardi E, Cetani F, et al. Genetic and clinical features of multiple endocrine neoplasia types 1 and 2. J Oncol. 2012; 2012: 705036

[9] Sonali T, Montserrat A-R, Lynn P, et al. The characterization of pheochromocytoma and its impact on overall survival in multiple endocrine neoplasia type 2. J Clin Endocrinol Metab. 2013; 98 : 1813-1819.

(Erdei Annamária dr., Debrecen, Nagyerdei krt. 98., 4032 e-mail: erdeianm@gmail.com)

A cikk a Creative Commons Attribution 4.0 International License (https://creativecommons.org/licenses/by/4.0/) feltételei szerint publikált Open Access közlemény, melynek szellemében a cikk bármilyen médiumban szabadon felhasználható, megosztható és újraközölhető, feltéve, hogy az eredeti szerző és a közlés helye, illetve a CC License linkje és az esetlegesen végrehajtott módosítások feltüntetésre kerülnek. (SID_1) 